\title{
The Initial Going-concern of Delisting Firms: An Application of Proportional Hazard Model
}

\author{
Chi-Chen Wang \\ Department of Financial Management, National Defense University \\ Yueh-Ju Lin \\ Department of Accounting, Kainan University \\ Yunsheng Hsu (Corresponding author) \\ Department of Accounting, National Chung-Hsing University
}

Received: May 27, 2013 Accepted: October 12, 2013 Published: December 1, 2013

doi:10.5296/ajfa.v5i2.4336 URL: http://dx.doi.org/10.5296/ajfa.v5i2.4336

\begin{abstract}
This paper examines the survival period and the factors of business failure of firms who have been issued with an initial going concern opinion (IGCO) by auditors. Empirical results show that financial variables are not significant predictors for future delisting crisis, but the corporate governance variables are especially for firms under deteriorating financial condition. Important factors causing the higher rate of delisting risk include shorter listing years, lower rate of retained earnings to total assets, lower rate of market value of equity to total debts, and higher rate of pledged shares of directors' and supervisors' within 7.5 quarters after the IGCO issued, the number of delisting firms reaches its peak, consistent with the existence of self-fulfilling prophecy. The hazard delisting function first rises to a peak at the $38^{\text {th }}$ quarter and then declines rapidly, showing that after the disclosure of IGCO, first nine years is the delisting crisis period for Taiwan public firms.
\end{abstract}

Keywords: Going concern, Business failure, Proportional hazard model, Survival analysis, Self-fulfilling prophecy 


\section{Introduction}

Most financial statements users apply audit opinions as an operational health checkup point to evaluate if the firm could operate normally or would fail in the future (Casterlla et al., 2002). Therefore, when firms are issued with an initial going-concern modified opinion by auditors, related parties may have various concerns about the IGCO firms. Financial statements users need to evaluate the length of future survival period in the listing market for the IGCO firms. Shareholders need to make selling decisions at an appropriate timing to avoid more losses. Creditors need to evaluate whether to demand for a debt repayment. Particularly when a higher credit risk is associated with borrowers, banks will consider the acceptance of future financing requests or simply demand for debt repayments. Government agencies also need to determine appropriate interventions to maintain financial orders. Therefore, further studies about the survival crisis for the IGCO firms are essentially useful to the related parties of delisting firms.

When firms are issued with IGCO, the firms have a higher probability to occur financial crisis. In financial accounting literature, there are two issues related to IGCO. First, after the disclosure of an adverse IGCO, whether the firms would go bankruptcy or whether the audit opinion could be an early warning predicting business bankruptcy has become an important research topic. Previous studies focus on the prediction powers of business bankruptcy by comparing audit opinions with statistical forecasting models. Most empirical evidences show that audit opinions do not exert higher prediction powers than those statistical models' (Altman and Mcgough, 1974; Koh, 1991). These results cause doubts on auditors' professional judgment, and some studies even suggest auditors to use statistical forecasting models to lower possible misjudgment in their evaluation (Altman, 1982; Koh and Killough, 1990; Levitan and Knoblett, 1985). Previous research simply uses a binary choice of failure or survival in the bankruptcy forecasting models in which only an accurate bankruptcy rate within the exact research period could be learned. However, because business failure is a lengthy and complicated process and even after issued with IGCO, some firms may still survive while others may bankrupt when time passes.

However, since firms have different survival periods and some may occur bankruptcy out of a research period, analysis assuming a same time period as a comparison basis would even causes the observed data to be censored. The problem will underestimate the probability of hazard rate of bankruptcy and cause errors in the analysis by wrongfully assuming the businesses are still in normal operation but actually its future failure is unpredictable. Therefore, the binary choice model does not consider the survival period of business failure in its forecasting models and thus lowers its effectiveness in future preventions and treatments. Understanding the time process about how firms go bankrupt is more useful than simply knowing its probability during the research period by the choice model. The survival analysis can further measure the survival time in addition to the probability of failure.

The second issue discussed in the financial accounting literature is to investigate the existence of self-fulfilling prophecy by examining if the bankruptcy probability increases during the first or second year after an IGCO issued. These studies, although considering the 
time process of business failure, merely limit their discussions to the primary effects of IGCO at an early stage. Actually after the disclosure of IGCO, financial impacts to corporate operations do not occur immediately but generally prolong to the future. Focusing on only one or two years after an adverse IGCO issued and when bankruptcy probability may not increase yet and impacts of future periods are ignored, result bias may occur in empirical inferences (Louwers et al., 1999). Therefore, after the disclosure of IGCO firms, for any point in time during the survival period, bankruptcy probability should be evaluated carefully. The survival analysis focuses on the timing issue by measuring a possible future bankruptcy risk for the IGCO firms when financial crisis occurs.

In addition, a related issue for financial statements users is about when to make their decisions. To overcome issues in previous studies and solve for actual problems for financial statements users, the entire time process, from the issuance of IGCO to their delisting, should be considered for these firms in financial crisis. Evaluation for the survival period before delisting and its delisting probability during the period is necessary for different users of financial statements to determine their further strategies.

This main characteristic in this paper is to connect audit opinions with the dynamic process of business failure, aiming at discussing the time process for a survival period until delisting for firms issued with an IGCO. We discuss three related issues of an IGCO, which are the hazard delisting period for Taiwan IGCO firms, the existence of self-fulfilling prophecy, and factors influencing the delisting.

Following previous financial crisis studies, we separate delisting factors based on corporate structures, the general, financial, operational, and shareholding structure. We construct a survival period model for financial crisis firms, covering from the time IGCO issued till delisting. Business failure occurs when many intervening factors cause its operation to cease or even withdraw from industry. Most related studies employ the choice model in the matching process of a business failure forecasting model to measure the most likely probability for survival or failure at a certain point in time. Their models use a static analysis which can merely evaluate the highest hazard rate for business failure or delisting during a certain period. Unfortunately, the complicated time process involved during the survival period is not investigated, for the process of either delisting from financial crisis or business failure from normal operation. Thus, possible timing for prevention and treatment has lost for firms in financial crisis. For instance, when a financial warning of IGCO issued, possible delisting time and its probability are still unknown. Then, if apply the survival analysis, delisting factors and the survival periods and probability can be estimated. This paper employs the proportional hazard models to estimate the delisting factors for Taiwan public companies. Our empirical results show that factors causing a higher delisting hazard rate are shorter listing time, lower rate of retained earnings to total assets, lower rate of market value of equity to total debts, and higher rate of pledge shares of directors' and supervisors'. We discover that after the sample been issued with an IGCO, its delisting risk rises continuously and reaches its peak at the $38^{\text {th }}$ quarter and then declines rapidly. Thus we conclude that Taiwan public firms have a nine-year delisting hazard period after the disclosure of an IGCO. 
In addition to the above introduction, the second section is literature review and the third section explains the design for econometric models. The fourth section describes the sample and data statistics, with the fifth section concluding our findings.

\section{Literature Review}

This section aims at improving previous financial crisis studies which ignore timing factor and by employing the survival analysis model, timing factor is incorporated with two research topics into our study. In addition, we also discuss the application of survival analysis in the empirical studies focusing on the industry and financial structure.

The first research topic is the comparison of prediction accuracy for corporate bankruptcy between audit opinions and statistical forecasting models. When corporate continuous operation is doubtful, auditors issue their going-concern opinions to caution public investors but not to predict bankruptcy. However, users of financial statements still consider the opinions as an early warning for business failure and regard a modified opinion as a financial checkup point (Casterlla et al., 2002). A study of Altman and Mcgough (1974) first connects audit opinion of going-concern quality with bankruptcy prediction. They collect a sample of 34 firms one year before bankruptcy during the years of 1970 to 1973 and employ a Z-score statistical forecasting model (Altman, 1968) to compare accuracy in bankruptcy prediction based on audit going-concern opinions. Their study finds that the statistical forecasting model has an accuracy rate of $82 \%$, almost doubling the audit opinions'. Thus they suggest auditors to apply statistical models to improve accuracy in their opinions. Other related studies also have similar findings that statistical forecasting models are superior than those of audit opinions in bankruptcy prediction (Altman, 1982; Koh, 1991; Koh and Killough, 1990; Levitan and Knoblett, 1985). Besides, a report by the Cohen commission (AICPA, 1978) also concerns the issue and International Federation of Accountants (1989) even requires more auditors' attention when issuing going-concern opinions. Although these suggestions cast a reasonable doubt on audit opinions, they also provide an objective auxiliary tool for auditors to apply.

Studies in bankruptcy prediction models are developed from the univariate to multivariate models, most of which have reviewed and based their methods from Altman (1968), Deakin (1972), and Ohlson (1980). Zavgren (1983) and Jones (1980) provide auditors with bankruptcy models as a professional reference. Their models are a binary choice model in which only accuracy but not bankruptcy probability is provided. Unfortunately, users of financial statements also concern the occurring time for bankruptcy in addition to its probability. During the survival period after an IGCO issued, users must evaluate associate risk and probability of bankruptcy at various times in searching for earlier strategies. However, the binary choice model does not discuss the survival period and the time process for business failure or delisting, and thus has lowered opportunities for early preventions and treatments. Therefore, understanding the changing process during survival period is meaningful in actual business practices when firms are in financial and delisting crisis.

The second research topic is an investigation about the existence of self-fulfilling prophecy. After an IGCO is issued, if bankruptcy probability increases within one or two years, the 
effect of self-fulfilling prophecy may exist. Louwers (1999) indicated that the IGCO opinion accelerates business failure and thus has impacts on current and potential investors, creditors, suppliers, and customers. Previous studies test the self-fulfilling prophecy by the percentage approach, calculating the ratio of bankrupt IGCO firms to the total IGCO firms. For example, in a sample of 78 IGCO Australian firms during the years of 1980 to 1992, Psaros and Zhang (1994) discover that after the first or second year of IGCO issued, 24 firms (37.2\%) declares bankruptcy. Within the same research period, Barnes and Hooi (1987) find that only 3 (5.9\%) out of a total sample of 51 IGCO firms occur bankruptcy within two years after IGCO issued. Besides, Altman (1982) states that about 25\% IGCO firms are bankrupt after IGCO issued. In conclusion, above studies do not support the existence of self-fulfilling prophecy. On the other hand, in a sample of 157 American IGCO firms during the years of 1983 to 1990, Nogler (1995) finds a 33\% sample declares bankruptcy after the first year of IGCO issued and supports the effect of self-fulfilling prophecy. In addition, in a sample of 210 IGCO American firms during the years of 1984 to 1991, Louwers (1999) states that 38 (18\%) firms are bankrupt after the first year of IGCO issued, 17 (8\%) firms after the second year. If applying the DTSA (discrete time survival analysis) modeling, it is $27 \%$ after the first year and $18 \%$ after the second year, which are similar to a $24 \%$ after the first year in the study of Citron and Taffer (1992) for a British IGCO sample. Both studies support the effect of self-fulfilling prophecy. Therefore, there is no conclusion about the existence of self-fulfilling prophecy for firms been issued with IGCO.

The inconclusive finding for self-fulfilling prophecy is due to the lack of an objective standard in the measurements of percentage approach. To present the effect of self-fulfilling prophecy, there is a need to investigate objective measurements for the effect of self-fulfilling prophecy. Zhang and Suzanne (1997) suggest applying the length of time for survival to measure the effect. However, the self-fulfilling prophecy seems to imply that IGCO must be issued before bankruptcy to occur. Because it is a complicate process for a normal corporation to declare bankruptcy, many factors could involve. Merely applying audit opinions to determine whether the firm will bankrupt after an early stage of IGCO issued seems incomprehensive. Besides, an IGCO is expected to exert its effect further to the future and other lagged effects may involve as well. Therefore, changes in the time process for audit opinions to exert impacts should be investigated further.

Finally, previous empirical studies find that the log-logistic model in survival analysis is the most appropriate method to match firms' survival period. Through the likelihood ratio test, an appropriate matching model can be obtained. However, if a quarter of the sample data is censored and if the selected parameter model assumes a final failing rate of one, the rate could easily be overestimated. In addition, the use of Weibull distribution assumption could also be used to build an early warning model for financial institutions. Bandopadhyyaya and Jaggia (2001), in a sample of 107 bankrupt firms during the years of 1979 to 1990, discuss the length of time and factors causing final bankruptcy after reorganization. They employ a split population duration model to perform tests and realistically consider the final bankruptcy rate not necessary equal to one. However, they do not explain the selection process of log-logistic modified model in their split population duration model. In conclusion, 
although the survival analysis is empirically applied to business studies, it is rarely applied to the study of audit opinions. Since financial distress occurs at different points in time which is a continuous process, it is more reasonable to use the survival period model to overcome the timing issue for our study.

\section{Econometric Models}

Logic or Probit method is generally used in the financial crisis literature which discusses the relation between the probability of financial distress and its factors. These methods imply that financial crisis occurs at the same time which simply separate the sample into occurring crisis or not. In order to distinguish different occurring time, this paper uses a periodical model to further separate the sample based on different delisting time. Our models consider the survival period so that the relation between corporate operating factors and delisting can be investigated correctly. The periodical model, also called the transition model, focuses on the length of time a status condition remains or the possibility of changing status at a certain point in time. The possibility is called the hazard rate, and the higher the rate is the shorter time the status remains. This paper discusses the relation between the hazard rate and corporate operating conditions (delisting). A higher hazard rate represents a worse operating condition, in which when the possibility of changing status from un-delisting to delisting is higher, the firm is more likely to occur delisting within a shorter time period.

The periodical model is applied in previous bankruptcy studies for financial institutions in which two models are generally used, the proportional hazard model and the accelerated failure time model (Lane, Looney and Wansley, 1986; Wheelock and Wilson, 1994). The two models have different assumption about its baseline hazard. The baseline hazard is set respectively as the following:

the proportional hazard model: $h(t \mid x)=h_{0}(t) \exp (x \beta)$,

the accelerated failure model: $h(t \mid x)=h_{0}(t, x \alpha) \exp (x \beta)$,

in which $h(t \mid x)$ is the hazard rate, $h_{0}(\cdot)$ is the baseline hazard, $x$ is the various predictors,

$\alpha$ and $\beta$ is the coefficient for its baseline and exponential function. From the above settings, the baseline hazard is assumed not to be affected by the predictors in the proportional hazard model, but otherwise in the accelerated failure model. Both models can apply parameter estimation methods, but Cox (1972) in his partial-likelihood approach for the estimation of proportional hazard model, assumes no baseline hazard for any pattern of distribution. Both models have different thresholds, characteristics, and applications. The following explains the use of proportional hazard model in this paper.

For the random variable $T$, representing days after IGCO, follows the probability distribution of $f(t \mid x)$ with an cumulative density function of $F(t \mid x)$. Within $t$ days after the IGCO, the delisting probability could be written as: 


$$
\operatorname{prob}(T \leq t \mid x)=F(t \mid x)=\int_{0}^{t} f(u \mid x) d u
$$

The delisting probability after t days in the survival function of $S(t \mid x)$ could be written as:

$$
S(t \mid x)=1-F(t \mid x)
$$

Thus, the hazard rate $h(t \mid x)$ for delisting occurring at $t$ days could be written as the following:

$$
h(t \mid x)=\lim _{\delta \rightarrow 0} \frac{\operatorname{prob}(t \leq T \leq t+\delta \mid T \geq t, x)}{\delta}=f(t \mid T \geq t, x)=\frac{f(t \mid x)}{S(t \mid x)} .
$$

From equation (1), (2) and (3), we can obtain the following three equations:

$$
\begin{gathered}
h(t \mid x)=\frac{-d \log S(t \mid x)}{d t} \\
f(t \mid x)=S(t \mid x) h(t \mid x) \\
S(t \mid x)=\exp \left(-\int_{0}^{t} h(u \mid x) d u\right) .
\end{gathered}
$$

To estimate the relation between variables and the survival period, any function set for $f(t \mid x), F(t \mid x), h(t \mid x)$, or $S(t \mid x)$ must be known. This paper follows Cox's (1972) partial log-likelihood method to estimate the proportional hazards model. The hazard rate is set as the following:

$$
h(t \mid x)=h_{0}(t) e^{x \beta}
$$

of which $\mathrm{x}$ describes the structures for listing firms and $\beta$ is the coefficient. Different characteristics of x may cause delisting effects differently, so the sign for each corresponding coefficient could be positive or negative. The baseline hazard $h_{0}(t)$ is the unobserved variable effects on the hazard rate. From equation (7), we can obtain the parameter function for $h(t \mid x)$ but not $h_{0}(t)$. Therefore, the proportional hazard model is called the semi-parametric estimation method. The estimation for $\beta$ is based on the partial-likelihood approach. This approach first arranges the sample in the order of the delisting and assumes $n$ number of listing firms in the sample. Thus, each $t$ in a listing firm 
satisfies $t_{1} \prec t_{2} \prec t_{3} \cdots$. When at $t_{1}$, the conditional delisting probability for the first firm is as the following:

$$
L_{1}=\frac{h\left(t_{1} \mid x_{1} \beta\right)}{\sum_{t=1}^{n} h\left(t_{1} \mid x_{1} \beta\right)}=\frac{e^{x_{1} \beta}}{\sum_{t=1}^{n} e^{x_{i} \beta}} .
$$

At $t_{j}$, the conditional delisting probability for the $j$ th firm is as the following:

$$
L_{j}=\frac{h\left(t_{j} \mid x_{j} \beta\right)}{\sum_{i=1}^{n} h\left(t_{i} \mid x_{i} \beta\right)}=\frac{e^{x_{j} \beta}}{\sum_{i=1}^{n} e^{x_{i} \beta}} .
$$

From equation (8) and (9), we can write the partial likelihood function, $P L$ as in the following:

$$
P L=\prod_{i=1}^{n} L_{i}=\prod_{i=1}^{n}\left[\frac{\exp \left(x_{i} \beta\right)}{\sum_{i=1}^{n} y_{i j} \times \exp \left(x_{j} \beta\right)}\right]^{\delta_{i}} .
$$

In equation (10), if $t_{j} \geq t_{i}$, then let $y_{i j}=1$ and if $t_{j} \prec t_{i}$, then let $y_{i j}=0$. If the data is censored, then $\delta_{i}=0$, and if not censored, then $\delta_{i}=1$. Therefore, a set of coefficients $\beta$ can be obtained in which the partial likelihood function reaches its maximum value. The $\beta$ set is our estimated targets. From the above, the proportional hazard model merely assumes the relation between the hazard rate and the baseline hazard. In equation (7), the hazard rate and the followed distribution in the survival period are not set. The main difference between the two models (the proportional hazards and the accelerated failure time) is in the assumption that the survival period follows a certain distribution. The model is set as the following:

$$
T=\exp (x \beta+\sigma \varepsilon)
$$

of which $T$ follows a certain distribution of $f(t), \sigma$ is the scale parameter, and $\varepsilon$ is the standard error term. We can write the likelihood function $L$ as the following:

$$
L=\prod_{t=1}^{n}\left[f_{i}\left(t_{i}\right)\right]^{\delta_{i}}\left[1-F_{i}\left(t_{i}\right)\right]^{1-\delta_{i}}=\prod_{i=1}^{n}\left[f_{i}\left(t_{i}\right)\right]^{\delta_{i}}\left[S_{i}\left(t_{i}\right)\right]^{1-\delta_{i}}
$$

When $\mathrm{L}$ is maximized, $\beta$ can be estimated. Note that the obtained signs in both models must be opposite, because when the survival period is shorter, the hazard rate will be higher.

In the accelerated failure model, the shape for hazard rate is different because it follows various distribution of $T$. In equation (11), non-linear relation between $T$ and variables can be found. Distribution in the standard error term $\mathcal{E}$ is not the same as $T$ 's, but a one-on-one 
switching relation. Table one is distributions for the survival period, the standard error term, and characteristics in its corresponding hazard rates. For these distributions, hazard rates have four different shapes, increasing, decreasing, no changing, or increasing first and then declining later. Therefore, when set the distribution for survival period, a life table must be used to describe the hazard rate first. Then based on the shape and characteristics in the hazard rate, a reasonable distribution for the survival period can be set, or there could be a specification error presented in the model.

Table 1. Distributions for $T, \mathcal{E}$, and hazard rate characteristics

\begin{tabular}{|c|c|c|}
\hline Distribution $T$ & Distribution $\varepsilon$ & Characteristics in $h(t)$ \\
\hline Exponential & $\begin{array}{l}\text { Extreme value } \\
\text { (1 parameter) }\end{array}$ & $h(t)$ is a fixed constant \\
\hline Gamma & Log-gamma & $h(t)$ increasing or decreasing \\
\hline Log-logistic & logistic & $h(t)$ first increasing/decreasing, then the opposite \\
\hline Log-normal & Normal & $h(t)$ first increasing, then decreasing \\
\hline Weibull & $\begin{array}{l}\text { Extreme value } \\
\text { ( } 2 \text { parameter) }\end{array}$ & $h(t)$ first decreasing, then increasing \\
\hline
\end{tabular}

Source : Allison (1995)

This paper studies a total sample of 153 delisting firms after been issued with an initial going-concern opinion (IGCO) by auditors. Research period covers from January 1, 1980 to June 30, 2006, a total of 16 years (64 quarters). Table 2 is the life table for the sample, arranged by the order of occurring period of delisting (in quarter time) based on a non-parametric analysis. As shown in Table 2, the IGCO sample have a high number of delisting firms during the quarters of 0 to 7.5 (31 firms), 7.5 to 15.0 (10 firms), 15.0 to 22.5 (29 firms), and 22.5 to 30.0 (13 firms) respectively. On the other hand, the rest of survival periods have only delisting firms of six, one, or zero. Particularly, after IGCO issued until the $7.5^{\text {th }}$ quarter, most IGCO firms occur delisting, showing that the effect of self-fulfilling prophecy exists in Taiwan capital market for our research period. During the same period (0 to $7.5^{\text {th }}$ quarter), the delisting probability continuously rises from 0.0328 to 0.1000 the highest rate, with a corresponding survival period from 30.0 to 37.5 quarters. Then, the hazard rate declines rapidly, meaning the average survival period for the IGCO firms to occur delisting is about 38 quarters (9 years). Within this period, the delisting probability is the highest, and then the hazard rate declines quickly until the quarter of 45 to 52.5, the rate rises to 0.0381 again. Graph 1 is a bar chart for the hazard rate and survival period based on table 2. The distribution pattern for hazard rate is different from those of corresponding hazard rates in 


\section{Macrothink}

Asian Journal of Finance \& Accounting ISSN 1946-052X 2013, Vol. 5, No. 2

table 1. Therefore, we decide not to apply the accelerated failure time model and employ the proportional hazard model instead by applying the Cox's partial log-likelihood approach.

Table 2. Life table ${ }^{1}$

\begin{tabular}{|c|c|c|c|c|c|c|}
\hline $\begin{array}{l}\text { Survival } \\
\text { period } \\
\text { (quarters) }\end{array}$ & $\begin{array}{l}\text { Sample } \\
\text { size }\end{array}$ & $\begin{array}{l}\text { Censored } \\
\text { firms }\end{array}$ & $\begin{array}{l}\text { Possil } \\
\text { delisti } \\
\text { firms }\end{array}$ & $\begin{array}{l}\text { Actual } \\
\text { delisting } \\
\text { firms }\end{array}$ & Survival rate & Hazard rate \\
\hline $\begin{array}{ll}0.0-\quad 7.5 \\
\end{array}$ & 153 & 23 & 141 & 31 & $1.000(0.000)^{2}$ & $0.0328(0.006)^{3}$ \\
\hline 7.5- 15.0 & 99 & 18 & 90 & 10 & $0.7809(0.035)$ & $0.0157(0.005)$ \\
\hline $15.0-22.5$ & 71 & 17 & 62 & 29 & $0.6941(0.040)$ & $0.0806(0.014)$ \\
\hline $22.5-30.0$ & 25 & 0 & 25 & 13 & $0.3721(0.049)$ & $0.0937(0.024)$ \\
\hline $30.0-37.5$ & 12 & 2 & 11 & 6 & $0.1786(0.044)$ & $0.1000(0.038)$ \\
\hline 37.5- 45.0 & 4 & 0 & 4 & 0 & $0.0812(0.033)$ & $0.0000(0.000)$ \\
\hline $45.0-52.5$ & 4 & 0 & 4 & 1 & $0.0812(0.033)$ & $0.0381(0.038)$ \\
\hline 52.5- 60.0 & 3 & 0 & 3 & 0 & $0.0609(0.031)$ & $0.0000(0.000)$ \\
\hline $60.0-67.5$ & 3 & 0 & 3 & 0 & $0.0609(0.031)$ & $0.0000(0.000)$ \\
\hline $67.5-75.0$ & 3 & 3 & 1 & 0 & $0.0609(0.031)$ & $0.0000(0.000)$ \\
\hline
\end{tabular}

Source: calculation from the sample

Remark 1: this table is based on Cutler and Ederer method.

2 : standard deviation is in brackets for the survival rate.

3 : standard deviation is in brackets for the hazard rate.

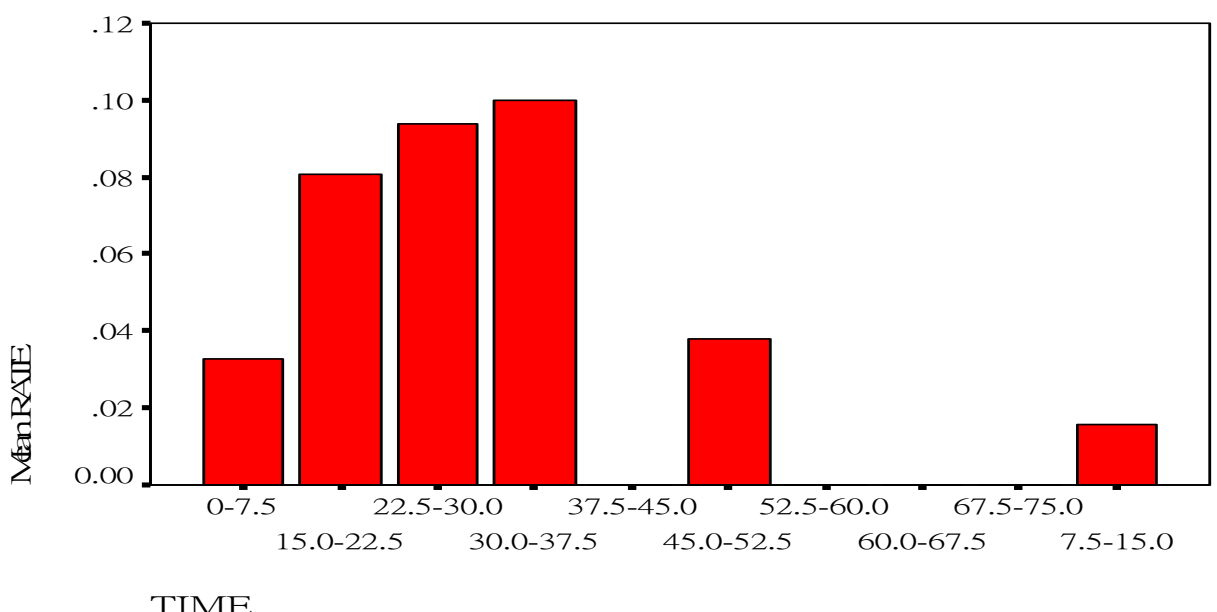

Graph 1. Hazard rate 


\section{Data and sample statistics}

Based on audit opinions on financial statements, excluding the unqualified opinion, this paper investigates auditors' initial going-concern opinion (IGCO) on listing companies. We employ important predictors for delisting from related literature to construct a survival analysis model. Corporate structures constructed in the predictors are financial information, stock prices, the pledged shares ratio of directors' and supervisors', and the insider shareholding ratio. Sample data is derived from the quarterly modules of cumulative financial information, full delivery share, or delisting company in the Taiwan Economic Journal (TEJ) databank.

The research period includes 64 quarters (16 years) from January 1, 1980 to June 30, 2006 and a total sample of 153 IGCO firms. Because a long complicated process is involved for a delisting crisis to occur, our study considers the survival period from the issuance of IGCO to the time of delisting (the failure event) or to research period stop date (right censored data). We take two points in time when the IGCO is issued and when the delisting occurs to calculate the actual survival period in quarters. During the research period for IGCO firms, a total final sample of 153 firms is obtained for modeling. To qualify as a delisting firm in this paper, the firm must be delisted by Taiwan Securities and Futures Bureau but not by voluntary delisting.

During the research period (1980/1/1 2006/6/30), if a survival period could be measured, a completed data for an IGCO delisting sample firm is obtained. However, if the delisting time is after the research stop date, the IGCO sample firm is considered un-delisting (right censored data) and has an incomplete survival data. For this incomplete survival data (right censored), its survival period is calculated by deducting the research stop date from the IGCO date. These incomplete survival data can only provide partial information due to the limitation on the research period stop date.

Table 3 lists the selected sample numbers, in which panel A is the sample selection process for financial distress firms. The first sample selection standard is to include only those IGCO firms who have complete financial statements and related information. Thus, four banking and securities IGCO firms with significant different accounting systems and 25 other IGCO firms with incomplete information are excluded. Finally, 153 IGCO firms are derived as our research sample at the research stop date of June 30, 2006.

Panel B in table 3 lists annual sample numbers of IGCO firms, delisting and un-delisting. Until the research stop date (2006/6/30), 68 IGCO firms are delisted and 85 IGCO firms are un-delisted. Based on the sample data, since 1998, numbers of IGCO firms increase , and delisting occurs mostly after 1998 . The main reason may due to the Asian financial crisis in 1997 which overturns economic condition, leading operating difficulties and depressing stock market continuously. During the period, many adverse cases such as inappropriate corporate investments or misappropriating corporate capital by large shareholders to maintain stock prices have caused corporate bankruptcy. 
Table 3. Sample Selection

Panel A: Sample selection process

\# of IGCO firms during 1980 - 2006

Less: Banking and securities companies

Less: Incomplete data information 25

Total number of final IGCO sample firms

153

Panel B: Annual sample selected

\begin{tabular}{|c|c|c|c|}
\hline Year & \# of IGCO firms & \# of delisting firms & \# of un-delisting \\
\hline 1980 & 0 & 0 & 0 \\
\hline 1981 & 0 & 0 & 0 \\
\hline 1982 & 1 & 1 & 0 \\
\hline 1983 & 0 & 0 & 0 \\
\hline 1984 & 0 & 0 & 0 \\
\hline 1985 & 0 & 0 & 0 \\
\hline 1986 & 1 & 1 & 0 \\
\hline 1987 & 2 & 2 & 0 \\
\hline 1988 & 1 & 1 & 0 \\
\hline 1989 & 0 & 0 & 0 \\
\hline 1990 & 0 & 0 & 0 \\
\hline 1991 & 2 & 2 & 0 \\
\hline 1992 & 0 & 0 & 0 \\
\hline 1993 & 0 & 0 & 0 \\
\hline 1994 & 1 & 0 & 1 \\
\hline 1995 & 3 & 3 & 0 \\
\hline 1996 & 1 & 1 & 0 \\
\hline 1997 & 0 & 0 & 0 \\
\hline 1998 & 20 & 14 & 6 \\
\hline 1999 & 14 & 9 & 5 \\
\hline 2000 & 18 & 10 & 8 \\
\hline 2001 & 30 & 10 & 20 \\
\hline 2002 & 12 & 4 & 8 \\
\hline 2003 & 9 & 3 & 6 \\
\hline 2004 & 19 & 7 & 12 \\
\hline 2005 & 19 & 0 & 19 \\
\hline 2006 & 0 & 0 & 0 \\
\hline Total & 153 & 68 & 85 \\
\hline
\end{tabular}




\section{Macrothink}

Table 4 is the sample statistics for the 153 IGCO sample firms by industry and listing market. It is generally believed public firms listing in the OTC market have smaller capital and unhealthier financial structure than those listing in the main stock market. This paper test the effect of type of listing market on delisting and find it is insignificant at a 0.05 confidence level with a correlation phi coefficient of 1.414 with p-value of 0.199 . Thus, empirically there is no significant correlation between delisting and listing market type in Taiwan for our IGCO sample firms. There is no difference between listing market type for delisting IGCO firms.

Table 4. Sample statistics for the IGCO firms

\begin{tabular}{|c|c|c|c|c|c|c|c|c|c|c|c|}
\hline & \multicolumn{5}{|c|}{ Delisted IGCO firms } & \multicolumn{6}{|c|}{ Un-delisted IGCO firms } \\
\hline & $\begin{array}{c}\text { Main } \\
\text { market }\end{array}$ & \multicolumn{2}{|c|}{$\begin{array}{c}\text { OTC } \\
\text { market }\end{array}$} & \multicolumn{2}{|c|}{ Total } & \multicolumn{2}{|c|}{$\begin{array}{c}\text { Main } \\
\text { market }\end{array}$} & \multicolumn{2}{|c|}{$\begin{array}{c}\text { OTC } \\
\text { market }\end{array}$} & \multicolumn{2}{|c|}{ Total } \\
\hline & $\%$ & \# & $\%$ & \# & $\%$ & \# & $\%$ & \# & $\%$ & $\#$ & $\%$ \\
\hline Cement & $\begin{array}{ll}0 & 0.00\end{array}$ & 0 & 0.00 & 0 & 0.00 & 1 & 1.18 & 0 & 0.00 & 1 & 1.18 \\
\hline Food & 913.24 & 0 & 0.00 & 9 & 13.24 & 1 & 1.18 & 0 & 0.00 & 1 & 1.18 \\
\hline Plastic & 11.47 & 0 & 0.00 & 1 & 1.47 & 2 & 2.35 & 0 & 0.00 & 2 & 2.35 \\
\hline Textile & 57.35 & 0 & 0.00 & 5 & 7.35 & 8 & 9.41 & 0 & 0.00 & 8 & 9.41 \\
\hline Machinery & $2 \quad 2.94$ & 0 & 0.00 & 2 & 2.94 & 0 & 0.00 & 0 & 0.00 & 0 & 0.00 \\
\hline Appliance & 11.47 & 0 & 0.00 & 1 & 1.47 & 2 & 2.35 & 0 & 0.00 & 2 & 2.35 \\
\hline Bio-chem & $\begin{array}{ll}0 & 0.00\end{array}$ & 0 & 0.00 & 0 & 0.00 & 1 & 1.18 & 1 & 1.18 & 2 & 2.35 \\
\hline Glass & 11.47 & 0 & 0.00 & 1 & 1.47 & 3 & 3.53 & 0 & 0.00 & 3 & 3.53 \\
\hline Paper & $\begin{array}{ll}0 & 0.00\end{array}$ & 0 & 0.00 & 0 & 0.00 & 1 & 1.18 & 0 & 0.00 & 1 & 1.18 \\
\hline Steel & $2 \quad 2.94$ & 1 & 1.47 & 3 & 4.41 & 5 & 5.88 & 2 & 2.35 & 7 & 8.24 \\
\hline Rubber & $\begin{array}{ll}0 & 0.00\end{array}$ & 0 & 0.00 & 0 & 0.00 & 1 & 1.18 & 0 & 0.00 & 1 & 1.18 \\
\hline Auto & 11.47 & 0 & 0.00 & 1 & 1.47 & 1 & 1.18 & 0 & 0.00 & 1 & 1.18 \\
\hline Electronics & $5 \quad 7.35$ & 7 & 10.29 & 12 & 17.65 & 13 & 15.29 & 14 & 16.47 & 27 & 31.76 \\
\hline Constructing & 68.82 & 4 & 5.88 & 10 & 14.71 & 9 & 10.59 & 3 & 3.53 & 12 & 14.12 \\
\hline Trading & 11.47 & 0 & 0.00 & 1 & 1.47 & 1 & 1.18 & 1 & 1.18 & 2 & 2.35 \\
\hline Tourism & $\begin{array}{ll}0 & 0.00\end{array}$ & 0 & 0.00 & 0 & 0.00 & 0 & 0.00 & 1 & 1.18 & 1 & 1.18 \\
\hline Communication & $\begin{array}{ll}0 & 0.00\end{array}$ & 1 & 1.47 & 1 & 1.47 & 0 & 0.00 & 0 & 0.00 & 0 & 0.00 \\
\hline Software & $\begin{array}{ll}0 & 0.00\end{array}$ & 0 & 0.00 & 0 & 0.00 & 0 & 0.00 & 2 & 2.35 & 2 & 2.35 \\
\hline Others & $2 \quad 2.94$ & 1 & 1.47 & 3 & 4.41 & 5 & 5.88 & 3 & 3.53 & 8 & 9.41 \\
\hline Managerial & 1725.00 & 1 & 1.47 & 18 & 26.47 & 4 & 4.71 & 0 & 0.00 & 4 & 4.71 \\
\hline total & 5377.94 & 15 & 22.06 & 08 & 100.00 & & 68.24 & 21 & 31.76 & 85 & 100.00 \\
\hline
\end{tabular}

Previous studies suggest auditors to apply corporate bankruptcy models as a tool to evaluate audit opinions. Due to its objective measurement and convenience in obtaining data, most 
statistical models employ financial ratios as main predictors. Cybinski and Winnsor (2005) also advise auditors to select appropriate information to reflect client operating conditions such as the financial ratios. Following previous studies (Altman, 1982, 1986; Chen and Lee, 1993; Ohlson, 1980, 1993), we classified the factors for financial distress into four corporate structures, the general, financial, operational, and ownership structure. The following explains these four corporate structures in detail.

Corporate general structure including firm size (SIZE) and firm age (AGE). Chen and Lee (1980) and Ohlson (1993) stated that the larger the firm size is, the less likely for financial crisis to occur. Chen and Lee (1993) showed that the higher the firm age, the less likely for delisting to occur.

Corporate financial structure could be evaluated by corporate short- and long-term solvency, and the worse the ability, the more likely financial crisis could occur. This paper employs four financial ratios to measure corporate solvency. Current ratio (CACL) is Current assets divided by current liabilities is current ratio. This ratio measure corporate liquidity, and the higher it is, the better short-term solvency is. Ohlson (1980) empirically proves that current ratio measures liquidity which is a significant indicator for corporate bankruptcy. Working capital to total assets ratio (WCTA) is the difference between total short-term assets and liabilities. Altman (1968) states that reducing of the firm's net current assets and liquidity will dampen its short-term solvency and increase the likelihood of delisting. Cash flows from operation to total liabilities (FUTL) is cash flows from operation divided by total liabilities. Beaver (1966) believes that this ratio reflects the amount of total liabilities its cash flows could bear. Total liabilities to total assets (TLTA) is total liabilities divided by total assets. Beaver (1966) and Ohlson (1980) reveal that this debt ratio has a significant prediction power for business financial crisis.

Financial crisis generally occurs due to a declining profitability from ineffective use of corporate capital. This paper studies the effectiveness in applying corporate capital and believes that the survival period for a financial crisis is related to its operational structure. Corporate operational structure explains the effectiveness in the use of capital. Returns on total assets (NITA) measure corporate profitability meaning the return that each dollar asset creates. Studies reveal that this rate is significantly associated with corporate financial crisis and the higher the rate, the better the profitability (Altman, 1968; Beaver, 1996; Ohlson, 1980). Altman (1968) uses retained earnings to total assets ratio (RETA) to measure the degree of earnings accumulated when time passes. Younger or profitless firms accumulate lower earnings which can lower this ratio and raise the delisting probability. Altman (1968) employs market value of equity to total liabilities (MVETL) to evaluate how the value of corporate assets declines when total debts exceed assets. If this ratio is low, a serious asset value declining problem and a solvency crisis may exist, which may thus increase the delisting probability.

Corporate governance studies investigate internal control mechanism. It is generally believed firms can effectively supervise and restraint managers' behaviors and lower their privileged consumption at corporate costs, resulting increases in firm value (Fama and Jensen, 1983; 
Jensen and Meckling, 1976). This line of literature focuses on the impacts of board characteristics and ownership structure on firm values. We use the pledged share ratio of directors' and supervisors' and insider shareholding ratio to proxy corporate ownership structure in our paper. Pledged share ratio of directors' and supervisors' (RATIO) is measured by the total pledged shares of directors' and supervisors' to their total shareholdings. When directors and supervisors pledge their shares, it seems that they withdraw their investments but remain ownership control. If the ratio is high, distortion in ownership structure become serious which may raise its delisting probability. Insider shareholding ratio (OWN) is measured by the total shareholdings of insiders (managers and directors) to the total outstanding shares. Beneish (1997) indicate that in larger companies, managers have lower shareholding ratios and thus less incentive to maximize firm values. Laporta et al. (1999) discover that when ownership is rather concentrated, firm value will be relatively higher. This paper uses shareholdings of managers', directors', and supervisors' to represent the insider shareholding ratio.

Table 5. Predict signs for predictors of delisting probability

\begin{tabular}{lll}
\hline & Predict & \\
Explanatory variables* & Sign & Definition \\
\hline Firm size(SIZE) & - & Log (total assets) \\
Firm age in years (AGE) & - & Years after establishment \\
Current ratio (CACL) & & Current assets/current debts \\
Working capital to total assets & - & (current assets - current debts)/total \\
(WCTA) & & assets \\
Total liabilities to assets (TLTA) & + & Total debts/total assets \\
Market value of equity to total & - & (market values of common and \\
liabilities (MVETL) & & preferred shares)/total debts \\
Cash flows to total liabilities & - & Operating cash flows/total debts \\
(FUTL) & & \\
Returns on assets (NITA) & - & Income before extraordinary \\
& & items/average total assets \\
Retained earnings to total assets & - & Retained earnings/total assets \\
(RETA) & & \\
Pledged shares \% of directors' & + & Pledged shares of directors' and \\
and supervisors' (RATIO) & & supervisors'/their total shares \\
Insider shareholding ratio & - & Shares of managers, directors, and \\
(OWN) & & supervisors/total outstanding shares \\
\hline
\end{tabular}

*above predictors use quarterly data in the information of financial, stock prices, pledged share ratios of directors' and supervisors', and insider share holding ratio. 
Based on the descriptive statistics in table 6, we find that the average of the IGCO observations is 15 quarters. Because certain firms have censored data, the average survival period is thus without actual meanings. The average age is 13 quarters, but the standard deviation is quite large at 9.7087, meaning that our sample firms are not concentrated at a certain year range, which is measured from the establishment to the beginning of our research period. The current ratio has an average value of $68 \%$, revealing a depressed short-term solvency for the IGCO sample.

Table 6. Descriptive statistics and Mean differences

\begin{tabular}{cccc}
\hline Variable & Mean & $\begin{array}{c}\text { Standard } \\
\text { deviation }\end{array}$ & Mean differences $^{*}$ \\
\hline TIME & 14.71241 & 12.04414 & 0.7524 \\
AGE & 13.18954 & 9.70807 & -0.4873 \\
SIZE & 14.78033 & 1.18690 & -0.3083 \\
CACL & 0.68113 & 0.44511 & 8.9689 \\
WCTA & -0.32609 & 0.59220 & $28.4319^{\mathrm{b}}$ \\
TLTA & 0.89929 & 0.44286 & $-27.1754^{\mathrm{b}}$ \\
FUTL & -0.00229 & 0.02856 & $-0.088 \%$ \\
RETA & -0.19611 & 0.36995 & $5.2631 \%$ \\
MVETL & 0.19678 & 0.40282 & $0.2623^{\mathrm{a}}$ \\
RATIO & 0.25968 & 0.33574 & $-16.3824 \%^{\mathrm{a}}$ \\
OWN & 0.01040 & 0.03812 & $-0.654 \%$ \\
\hline
\end{tabular}

a is significant at a 0.01 level, and ${ }^{\mathrm{b}}$ is significant a 0.05 level.

*is the difference between the delisting firms and those remaining operation at the end of 2006.

\section{Empirical results}

Information is costly and some are even limited or not obtainable when investors need useful information to make investment decisions. This paper applies both financial and no financial information to investigate delisting factors for IGCO firms. Our study examines four models of corporate structure combinations under insufficient or sufficient information assumption. For insufficient information assumption, three structure models, the general financial, general operation, and general ownership are tested respectively. The sufficient information model has all corporate financial and non-financial structures into the model, including the general, financial, operational, and ownership structure. We discuss the relation between different corporate structures and its delisting and search for significant impact predictors for corporate delisting. Table 7 includes our empirical results. According to model 1 in table 7, insignificant financial predictors for delisting are current ratio (CACL), working capital to total assets ratio 


\section{Macrothink}

(WCTA), debt ratio (TLTA), and market value of equity to total debt ratio (MVETL). The result shows that ratios in financial structure are inefficient predictors for delisting.

Model 2 includes three ratios of returns on assets (NITA), retained earnings to total assets (RETA), and market value of equity to total debts (MVETL) in corporate operational structure to its impacts on delisting. Among these ratios, the retained earnings to total assets (RETA) ratio has a significant and negative impact on delisting. When in financial distress, corporate performance and profit decline which reduce accumulated earnings as a result. This shows that inappropriate application of corporate resources may cause its assets to function incompletely. In addition, the market value of equity to total debts ratio (MVETL) is also significant and negative. After the issuance of IGCO, corporate stock prices fall, market values shrink, and debt paying ability even lowers, resulted in a higher delisting probability.

Model 3 has two ratios in the corporate ownership structure to predict delisting, including the pledged share rate of directors' and supervisors' and insider shareholding ratio. Among these two ratios, the insider shareholding ratio has a significant and positive effect on delisting. Large ownership shareholders pledge their shares to obtain capital and make inappropriate investment decisions, causing corporate financial crisis as a result. This situation is normally observed in Taiwan public companies and eventually they are desisted from the market. Model 4 incorporates all four corporate structures into the model when information is sufficient to exam its impacts on delisting. The empirical results show two significant and negative impacts on delisting, the retained earnings to total assets ratio (RETA) and the market value of equity to total debts ratio (MVETL). The pledged share ratio of directors' and supervisors' has a significant and negative impact, meaning that applying operational and non-financial ownership structure together into the model is useful in predicting corporate delisting. 
Table 7. Empirical results based on the proportional hazard model

\begin{tabular}{|c|c|c|c|c|}
\hline & Mode 1 & Model 2 & Model 3 & Model 4 \\
\hline CACL & $-0.315(0.276)$ & & & $-0.107(0.289)$ \\
\hline WTCA & $0.216(0.241)$ & & & $-0.082(0.270)$ \\
\hline TLTA & $0.209(0.351)$ & & & $0.156(0.451)$ \\
\hline FUTL & $1.895(3.812)$ & & & $4.535(3.948)$ \\
\hline NITA & & $-24.79(48.36)$ & & $-15.26(56.557)$ \\
\hline RETA & & $-0.680(0.404)^{*}$ & & $-0.747(0.416)^{*}$ \\
\hline MVETL & & $-0.924(0.295)^{* * * *}$ & & $-0.991(0.416)^{* * *}$ \\
\hline RATIO & & & $0.978(0.364)^{* * *}$ & $0.857(0.407)^{* *}$ \\
\hline OWN & & & $-1.140(3.120)$ & $-0.509(3.337)$ \\
\hline AGE & $-0.044(0.014)^{* * *}$ & $-0.049(0.014)^{* * *}$ & $-0.041(0.014)^{* * *}$ & $-0.049(0.014)^{* * *}$ \\
\hline SIZE & $-0.093(0.099)$ & $-0.103(0.098)$ & $-0.027(0.097)$ & $-0.069(0.104)$ \\
\hline Log-likelihood & -357.224 & -353.186 & -354.516 & -350.046 \\
\hline $\begin{array}{l}\text { Restrict } \\
\text { Log-L slope }=0\end{array}$ & -365.859 & -365.859 & -365.859 & -365.859 \\
\hline
\end{tabular}

Standard deviation in the brackets, *, **, and ***represent significant at the level of $0.05,0.025$, and 0.01 .

Model 1 includes corporate general and financial structure.

Model 2 includes corporate general and operational structure.

Model 3 includes corporate general and ownership structure.

Model 4 includes corporate general, financial, operational, \& ownership structure.

\section{Conclusion}

After the issuance of an initial going-concern opinion (IGCO), users of financial statements concern about whether the firm will be delisted from the market, or it will depart from financial crisis and continue its operation. Previous studies suggest employing the binary choice model as a tool for auditors to evaluate the issue of going-concern for the firm. The choice model is used to predict future business failure possibility, and early relevant impacts of IGCO. On the other hand, important issues that capital markets concern about is the occurring time for delisting, the maximum delisting probability, or the length of survival period after the opinion by IGCO firms. Furthermore, because the binary choice model can only simply to predict the maximum delisting probability, the timing process for delisting cannot be fully understood, which may lower the prevention and treatment function in crisis forecasting models.

We employ the proportional hazard model on the sample of Taiwan IGCO delisting firms to discuss the delisting dynamic process after been issued with an IGCO. First, we obtain a life table from the research period data by a non-parametric analysis and learn that after 38 
quarters from IGCO issued, the sample has a highest delisting probability during our research period. After issued with an IGCO, the delisting hazard period is about nine years, with a high delisting probability of $10 \%$. This paper applies four corporate structures to measure impact factors on the delisting function and find that except for the ratios of equity to total debts and retained earnings to total assets, explanatory variables in corporate financial structure are all insignificant factors. However, the pledged share ratio of directors' and supervisors' in ownership structure, representing corporate governance has a significant and positive impact on delisting.

Generally, objective financial information can be used to measure operational performance. Auditors issue the going-concern modified opinion based on their professional judgment about clients' financial statements and relevant information. When such a modified IGCO is issued, unhealthy financial structure of the firm has already existed for a long time. Then it would be misled by these financials to evaluate its future operational performance. By assisting with non-financial information, decisions about a delisting crisis for IGCO firms can be evaluated. Among our results, corporate governance structure is proved to be an important index. However, our results reflect that by merely applying financial information to evaluate factors for delisting in Taiwan IGCO sample is insufficient. More importantly, the result shows that corporate governance mechanism is related to the issue of going-concern operation.

\section{References}

Altman, E. I., \& T. P. McGough. (1974). Evaluation of a company as a going concern. Journal of Accountancy, 50-57.

Altman, E. I. (1982). Accounting implications of failure prediction models. Journal of Accounting, Auditing and Finance, 4-19.

Bandopadhyaya, A., \& S. Jaggia. (2001). An analysis of second time around bankruptcies using a split-population duration model. Journal of Empirical Finance, 201-218. http://dx.doi.org/10.1016/S0927-5398(01)00023-8

Beaver, W. (1996). Financial ratios as predictors of failure. Journal of Accounting Research, 71-117.

Beneish, M. D. (1997). Detecting GAAP violation: implications for assessing earnings management among firms with extreme financial performance. Journal of Accounting and Public Policy, 271-309. http://dx.doi.org/10.1016/S0278-4254(97)00023-9

Barnes, P., \& Hooi, D. (1987). The stranger case of the qualified success. Accountancy, 32-33.

Casterella, J. R., B. L. Lewis, \& P. L. Walker. (2001). The relation of audit opinion and auditor change with bankruptcy emergence. AAA audit section midyear meeting.

Citron, D. B., \& R. J. Taffler. (1992). The audit report under going-concern uncertainties: An empirical analysis. Accounting and Business Research, 22(4), 337-345. http://dx.doi.org/10.1080/00014788.1992.9729449 
Chen, Ko, \& J. Lee. (1993). Financial ratios and corporate endurance: A case of the oil and gas industry. Contemporary Accounting Research, 9(2), 667-694.

http://dx.doi.org/10.1111/j.1911-3846.1993.tb00903.x

Deakin, E. B. (1972). A discriminant analysis of predictors of business failure. Journal of Accounting Research, 167-179. http://dx.doi.org/10.2307/2490225

Jensen, M., \& W. Meckling. (1976). Theory of the firm: Managerial behavior agency costs and ownership structure. Journal of Financial Economics, 305-360. http://dx.doi.org/10.1016/0304-405X(76)90026-X

Koh, H. C., \& L. N. Killough. (1990). The use of multiple discriminant analysis in the assessment of the going-concern status of an audit client. Journal of Business Finance and Accounting, 178-192.

Koh, H. C. (1991). Model predictions and auditor assessments of going-concern status. Accounting and Business Research, 2L(4), 331-338.

Levitan, A., \& Knoblett, J. (1985). Indicator of exceptions to the going concern assumption. Auditing: a Journal of Practice \& Theory, 5, 26-39.

Louwers, T, Messina, F., \& Richard, M. (1999). The auditors going concern disclosure as a self-fulfilling prophecy: A discrete time survival analysis. Decision Sciences, 30(3), 805-824. http://dx.doi.org/10.1111/j.1540-5915.1999.tb00907.x

Laporta, R., F. Lopez-de-Silanes, \& A. Shleifer. (1999). Corporate ownership around the world. Journal of Finance, 54, 471-517. http://dx.doi.org/10.1111/0022-1082.00115

Lancaster, T. (1990). The Econometric Analysis of Transition Data. Brown University. PMCid:PMC53443

Zhang, M. W., \& H. Suzanne. (1997). Going, going ...gone? Is a GCQ a self - fulfilling Prophecy. Australian Accountant, 22-23.

Nogler, G. E. (1995). The resolution of auditor going - concern opinions. Auditing: A Journal of Practices \& Theory, 14(2), 54-73.

Ohlson, J. (1980). Financial ratios and the probabilistic prediction of bankruptcy. Journal of Accounting Research, 18(1), 109-131. http://dx.doi.org/10.2307/2490395

Psaros, J. and M. Zhang. (1994). The going concern audit opinion: Australian evidence. Perspective on Contemporary Auditing, 39-46.

Cybinski, P., \& W. Carolyn. (2005). The efficacy of auditor's going-concern opinions compared with a temporal and an temporal bankruptcy risk model: analyzing U.S trade and service industry failures 1974-1988. Pacific Accounting Review, 3-36.

Schmidt, P., \& A. D. Witte. (1989). Predicting criminal recidivism using split population survival time model. Journal of Econometrics, 40, 141-159. http://dx.doi.org/10.1016/0304-4076(89)90034-1 